\title{
Corrosion Evaluation of INTEC Waste Storage Tank WM-182
}

Published November 15, 1999

Idaho National Engineering and Environmental Laboratory High Level Waste Program Division Bechtel BWXT Idaho, LLC Idaho Falls, Idaho 83415

Prepared for the

U.S. Department of Energy

Under DOE Idaho Operations Office Contract DE-AC07-991D13727 


\section{DISCLAIMER}

This report was prepared as an account of work sponsored by an agency of the United States Government. Neither the United States Government nor any agency thereof, nor any of their employees, make any warranty, express or implied, or assumes any legal liability or responsibility for the accuracy, completeness, or usefulness of any information, apparatus, product, or process disciosed, or represents that its use would not infringe privately owned rights. Reference herein to any specific commercial product, process, or service by trade name, trademark, manufacturer, or otherwise does not necessarily constitute or imply its endorsement, recommendation, or favoring by the United States Government or any agency thereof. The views and opinions of authors expressed herein do not necessarily state or reflect those of the United States Government or any agency thereof. 


\section{DISCLAIMER}

Portions of this document may be illegible in electronic image products. Images are produced from the best available original document. 


\section{SUMMARY}

Irradiated nuclear fuel has been stored and reprocessed at the Idaho National Engineering and Environmental Laboratory since 1953 using facilities located at the Idaho Nuclear Technology and Engineering Center (INTEC). This reprocessing produced radioactive liquid waste which was stored in the Tank Farm. The INTEC Tank Farm consists of eleven vaulted 300,000-gallon underground tanks including Tank WM-182. Tank WM-182 was put into service in 1955, has been filled four times, and has contained aluminum and zirconium fuel reprocessing wastes as well as sodium bearing waste.

A program to monitor corrosion in the waste tanks was initiated in 1953 when the first of the eleven Tank Farm tanks was placed in service. Austenitic stainless steel coupons representative of the materials of construction of the tanks are used to monitor internal tank corrosion. Corrosion coupons have been retrieved from the tanks and analyzed four times, in 1962, 1976, 1983, and 1988. In 1988, new corrosion coupon assemblies were added to the tanks, including WM-182, to monitor the conditions on the tank bottom. In 1999, the remaining 45 corrosion coupons were retrieved from Tank WM-182 and analyzed. These corrosion coupons consisted of 40 sections of seamless Type 304L pipe and five welded and machined Type 304L plate type samples.

This report documents the final inspection of the WM-182 corrosion coupons. Physical examination of the welded corrosion test coupons exposed to the tank bottom conditions of Tank WM-182 revealed very light uniform corrosion. Examination of the external surfaces of the extruded pipe samples showed very light uniform corrosion with slight indications of preferential attack parallel to extrusion marks and start of end grain attack of the cut edges. These indications were only evident when examined under stereo microscope at magnifications of $20 \mathrm{X}$ and above. There were no definite indications of localized corrosion, such as cracking, pitting, preferential weld attack, or weld heat affected zone attack on either the welded or extruded coupons. Visual examination of the coupon support cables, where they were not encased in plastic, failed to reveal any indication of liquid-vapor or liquid-liquid interface attack or any crevice corrosion.

Based on the WM-182 coupon evaluations, which have occurred throughout the life of the tank, the metal loss from the tank wall due to uniform corrosion is not expected to exceed $5.5 \times 10^{-1}$ mil $(0.00055 \mathrm{inch})$. For purposes of waste storage, this is a negligible amount of metal loss. Localized corrosion such as cracking, pitting, preferential weld attack, or weld heat affected zone attack is not expected to be a materials problem in the tank. 


\section{CONTENTS}

Summary ....................................................................................................................

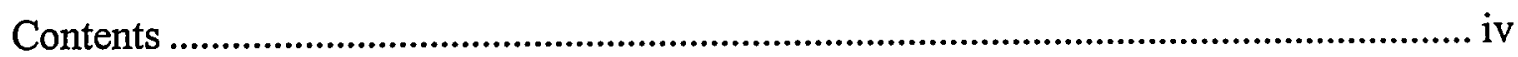

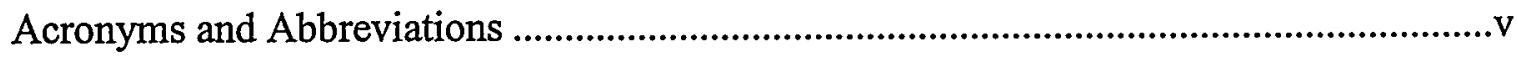

1. Introduction...............................................................................................................

2. Corrosion Monitoring and Test Procedure …...................................................................

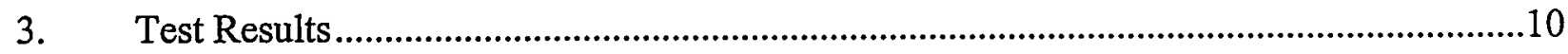

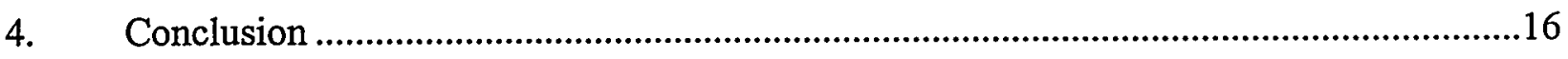

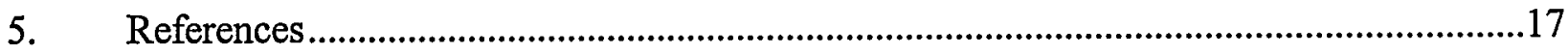

\section{FIGURES}

1. Tank Farm Status....................................................................................................................

2. Typical Liquid Waste Tank at INTEC .................................................................................

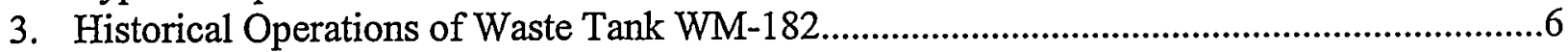

4. Corrosion Specimen Test Jig..................................................................................................

5. Corrosion Coupon Assembly for Tank Bottom Evaluation ........................................................9

6. Typical Tank Bottom Corrosion Coupon after 11.4 Years Exposure ......................................12

7. Typical Seamless Pipe Corrosion Coupon after 28.3 Years Exposure ....................................12

8. Welded Bottom Type 304L Stainless Steel Coupons - 0 Inch Level (Tank Bottom) ...........13

9. Seamless Type 304L Stainless Steel Pipe Corrosion Coupons - 18 Inch Level .....................13

10. Seamless Type 304L Stainless Steel Pipe Corrosion Coupons - 36 Inch Level .....................14

11. Seamless Type 304L Stainless Steel Pipe Corrosion Coupons - 72 Inch Level ....................14

\section{TABLES}

1. Typical Liquid Waste Chemical Compositions ...............................................................................

2. Summary of 1999 Corrosion Coupon Data for Waste Tank WM-182 .....................................15

3. Summary of Corrosion Coupon Data for the Life of Tank WM-182 ......................................15 


\section{ACRONYMS and ABBREVIATIONS}

APS

CPP

DOE

DR

ENICO

HLW

ICP

ICPP

IDO

INEEL

INTEC

LR

mil

mpy

PR

RCRA

RTD

SBW

SNF

SS

VOG

WINCO

WL

WM
Atmospheric Protection System

Chemical Processing Plant

Department of Energy

Density Recorder

Exxon Nuclear Idaho Company reports identifier

High-level waste

Allied Chemical Corporation reports identifier

Idaho Chemical Processing Plant

Idaho Operation Office reports identifier

Idaho National Engineering and Environmental Laboratory

Idaho Nuclear Technology and Engineering Center

Level Recorder

0.001 inch

Mils per Year

Pressure Recorder

Resource Conservation and Recovery Act

Resistance Temperature Detector

Sodium Bearing Waste

Spent Nuclear Fuel

Stainless Steel

Vessel Off Gas

Westinghouse Idaho Nuclear Company reports identifier

$\mathrm{AE}$ area designator for radioactive liquid waste management

$\mathrm{AE}$ area designator for highly radioactive liquid waste management 


\section{Corrosion Evaluation of INTEC Waste Storage Tank WM-182}

\section{INTRODUCTION}

Irradiated nuclear fuel has been stored and reprocessed at the Idaho National Engineering and Environmental Laboratory (INEEL) since 1953 using facilities located at the Idaho Nuclear Technology and Engineering Center (INTEC) (formerly the Idaho Chemical Processing Plant or ICPP). Historically, spent nuclear fuel (SNF) was brought to INTEC from a variety of reactors throughout the world and was stored either underwater in pools or in dry storage facilities for an interim period. Some of the SNF was chemically reprocessed to recover uranium, lanthanum, neptunium, and krypton for the Department of Energy (DOE) and its predecessor organizations. This reprocessing produced radioactive liquid waste, which was stored in the Tank Farm. Since 1963, most of this liquid waste has been solidified using a process called calcination.

Calcination evaporates the water and other volatiles from the liquid waste and converts the remaining materials to dry granular solids. The calcine solids from this process are stored in specially designed stainless steel storage bins contained in concrete vaults. Two types of liquid waste have been stored; they are high level waste (HLW) and sodium bearing waste (SBW). The $\mathrm{HLW}$ was generated as a direct result of reprocessing SNF. The composition of the HLW was dependent on the types of fuel being processed, with the aluminum, zirconium, and Fluorinel dissolution processes producing the greatest volumes of waste. The SBW was generated from incidental activities, such as decontamination, associated with operation of the INTEC. Typical chemical compositions of these liquid wastes are shown in Table 1.

The INTEC Tank Farm was constructed during the 1950s and 1960s and has been in continuous use since 1953. It consists of eleven vaulted 300,000-gallon underground tanks in which the liquid wastes are stored (Figure 1). This facility is significantly different from other tank farms in the DOE complex in three respects. First, the tanks are constructed of stainless (not carbon) steels. Second, the wastes are stored in the acidic (not neutralized or alkaline) condition, thereby avoiding most of the technical problems, including corrosion and leaking tanks, that have occurred at other locations ${ }^{1}$. Third, the tanks have been repeatedly emptied and refilled over the years as liquid wastes were periodically withdrawn to be calcined and as additional new wastes were generated from continued fuel reprocessing. Stainless steels are particularly well suited for service with acidic nitrate solutions. Stainless steel surfaces are protected by a passivation layer of chromic oxide $\left(\mathrm{Cr}_{2} \mathrm{O}_{3}\right)$ that is reinforced by the presence of oxidizing nitrate. Although liquid waste leaks have occasionally occurred in associated valves and piping, no liquid waste leaks from the waste tanks have ever occurred.

\footnotetext{
${ }^{1}$ The DOE sites at Hanford and Savannah River neutralized their wastes and stored them in carbon steel tanks. However, after four decades of waste storage, the carbon steel tanks have developed leaks that have allowed liquid waste to escape to the environment.
} 
This report documents the inspection of the corrosion coupons installed in Tank WM-182 which was put into service in 1955. The tank is contained in an octagonal, pillar-and-panel concrete vault. The tank is 50 feet in diameter, is constructed of 304L stainless steel, and has a side wall that is 21 feet high (Figure 2). The tank walls range from 5/16 inch thick at the bottom to 3/16 inch at the top. The tank has a nominal volume of 300,000 gallons, but the operating volume is not allowed to exceed 285,000 gallons. The tank is equipped with cooling coils to remove excess heat from the waste solution if required. The tank has been filled four times and has contained aluminum and zirconium fuel reprocessing wastes, as well as SBW (Figure 3). The tank will be flushed with water and emptied to heel level prior to June $30,2003^{2}$. This tank will be closed in conformance with the Resource Conservation and Recovery Act (RCRA); it will be the first tank to be closed in the Tank Farm.

\footnotetext{
2 June 30, 2003 is the cease use date for the pillar and panel vaulted tanks as mandated by the Second Modification to the Notice of Noncompliance Consent Order.
} 
Table 1. Typical Liquid Waste Chemical Compositions.

\begin{tabular}{|c|c|c|c|c|c|}
\hline Major Species & Units & Zirconium & Fluorinel & Sodium Bearing & Aluminum \\
\hline Acid $\left(\mathrm{H}^{+}\right)$ & Molar & 1.4 & 1.5 & 1.28 & 0.81 \\
\hline Aluminum (Al) & Molar & 0.68 & 0.43 & 0.57 & 1.5 \\
\hline Zirconium (Zr) & Molar & 0.41 & 0.31 & & \\
\hline Boron (B) & Molar & 0.19 & 0.15 & 0.017 & \\
\hline Cadmium (Cd) & Molar & & 0.05 & 0.001 & \\
\hline Sodium $(\mathrm{Na})$ & Molar & 0.017 & 0.02 & 1.50 & 0.06 \\
\hline Potassium (K) & Molar & 0.003 & & 0.17 & \\
\hline Chromium (Cr) & Molar & 0.015 & 0.015 & & \\
\hline $\operatorname{Iron}(\mathrm{Fe})$ & Molar & 0.007 & 0.005 & 0.002 & 0.01 \\
\hline $\operatorname{Tin}(\mathrm{Sn})$ & Molar & 0.005 & 0.004 & & \\
\hline Mercury (Hg) & Molar & & & 0.0013 & 0.02 \\
\hline Fluoride (F) & Molar & 3.20 & 2.10 & 0.04 & \\
\hline Chloride $(\mathrm{Cl})$ & $\mathrm{mg} / \mathrm{L}$ & & 50 & 1000 & \\
\hline Nitrate $\left(\mathrm{NO}_{3}\right)$ & Molar & 2.30 & 1.90 & 4.50 & 5.40 \\
\hline Sulfate $\left(\mathrm{SO}_{4}\right)$ & Molar & & 0.035 & 0.043 & \\
\hline Uranium (U) & $\mathrm{mg} / \mathrm{L}$ & 1.30 & 6.5 & 66.4 & \\
\hline Undissolved Solids & $g / L$ & 2.0 & 2.0 & 2.4 & \\
\hline Liquid Density & $\mathrm{g} / \mathrm{mL}$ & 1.20 & 1.15 & 1.25 & 1.28 \\
\hline
\end{tabular}




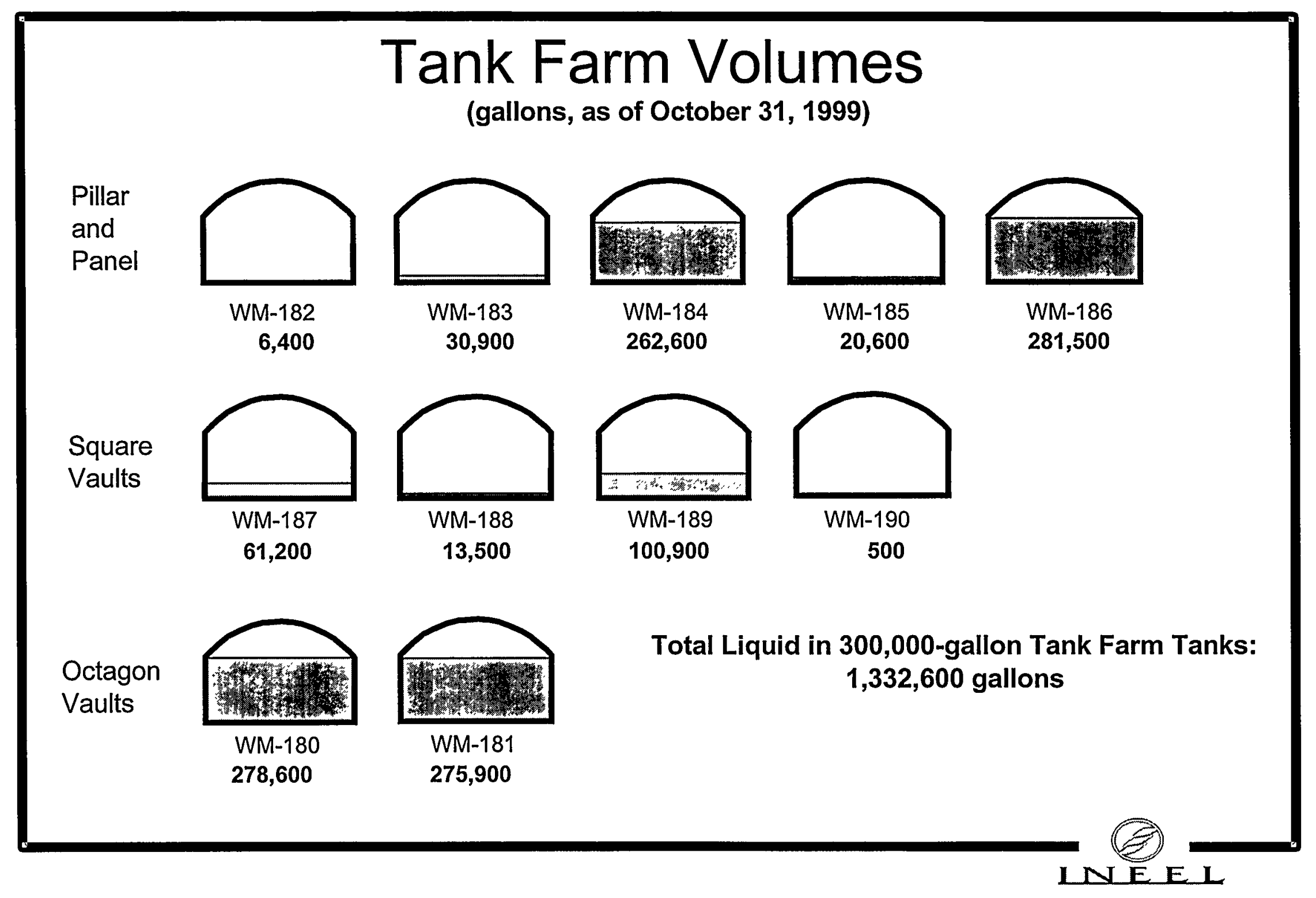

Figure 1. Tank Farm Status. 


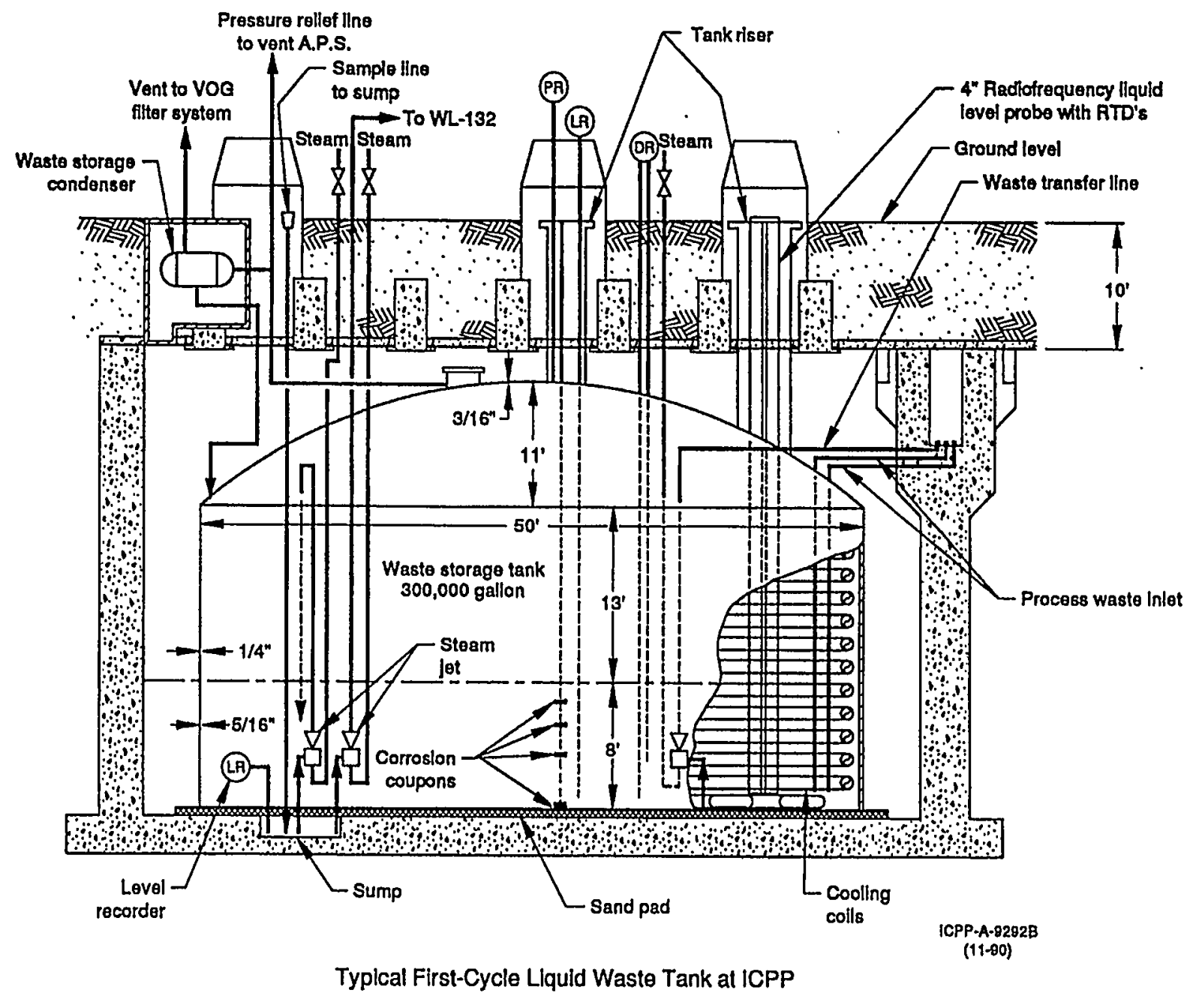

Figure 2. Typical Liquid Waste Tank at INTEC. 


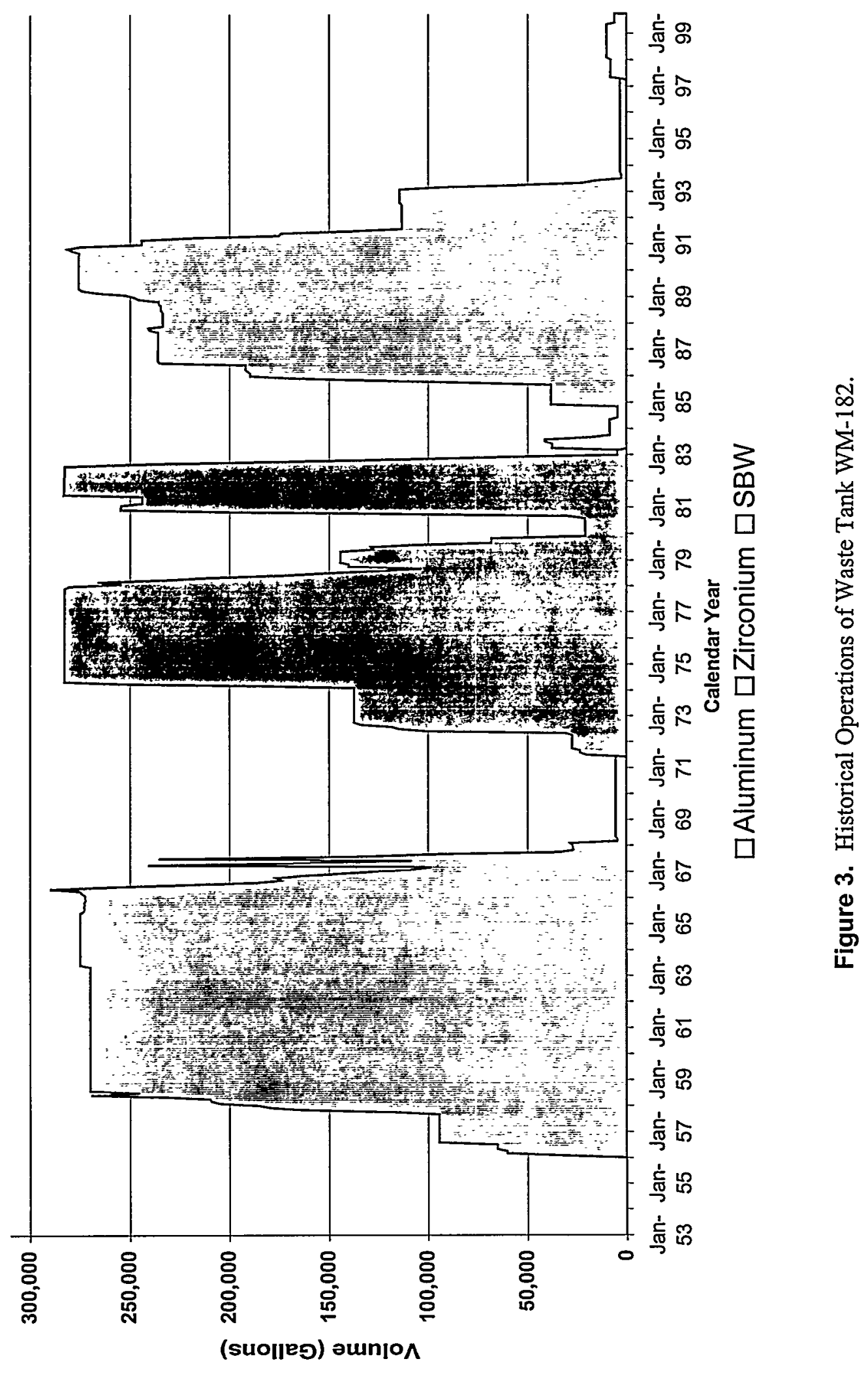




\section{CORROSION MONITORING AND TEST PROCEDURE}

A program to monitor corrosion in the waste tanks was initiated in 1953 when the first of the eleven Tank Farm tanks was placed in service. Type 304L stainless steel corrosion coupons, representative of the materials of construction of the tanks, are used to monitor the tank condition. The initial corrosion monitoring plans were to retrieve a set of coupons approximately every ten years in order to monitor their progressive corrosion behavior in the actual waste storage environment.

The corrosion test coupons in Tank WM-182 are round seamless pipe sections. These coupons are held on test jigs (Figure 4) which are fabricated of austenitic (Type 304L) stainless steel and suspended in the waste tanks by clamping onto stainless steel cables at the 18-inch, 36-inch, and 72-inch levels above the tank bottom. The test coupons are held on hooks welded to the support assembly. During the corrosion coupon recovery operation in 1987-1988 (Reference 4 ), additional welded corrosion coupons (Figure 5) were placed in all eleven waste tanks. These coupons are exposed on or near the tank bottom to measure the corrosion that is occurring in this previously unmonitored area. Corrosion coupons have been retrieved from the tanks and analyzed four times, in the past: 1962, 1976, 1983, and 1988 (References 1, 2, 3, 4).

The coupons removed from the tanks are carefully decontaminated in a manner that will not significantly affect the coupon surfaces with respect to their appearances or amounts of surface material that might have corroded away. Blank or control coupons accompany actual tank coupons through the decontamination process, so any corrosive effects from the decontamination can be recognized and given appropriate consideration in the interpretation of the results. The coupons are weighed in order to determine weight losses from which the rates of uniform corrosion can be determined. The coupons are also examined microscopically for indications of localized corrosion, such as cracking, pitting, preferential weld attack, or weld heat affected zone attack. The corrosion data are then evaluated and the results reported. 


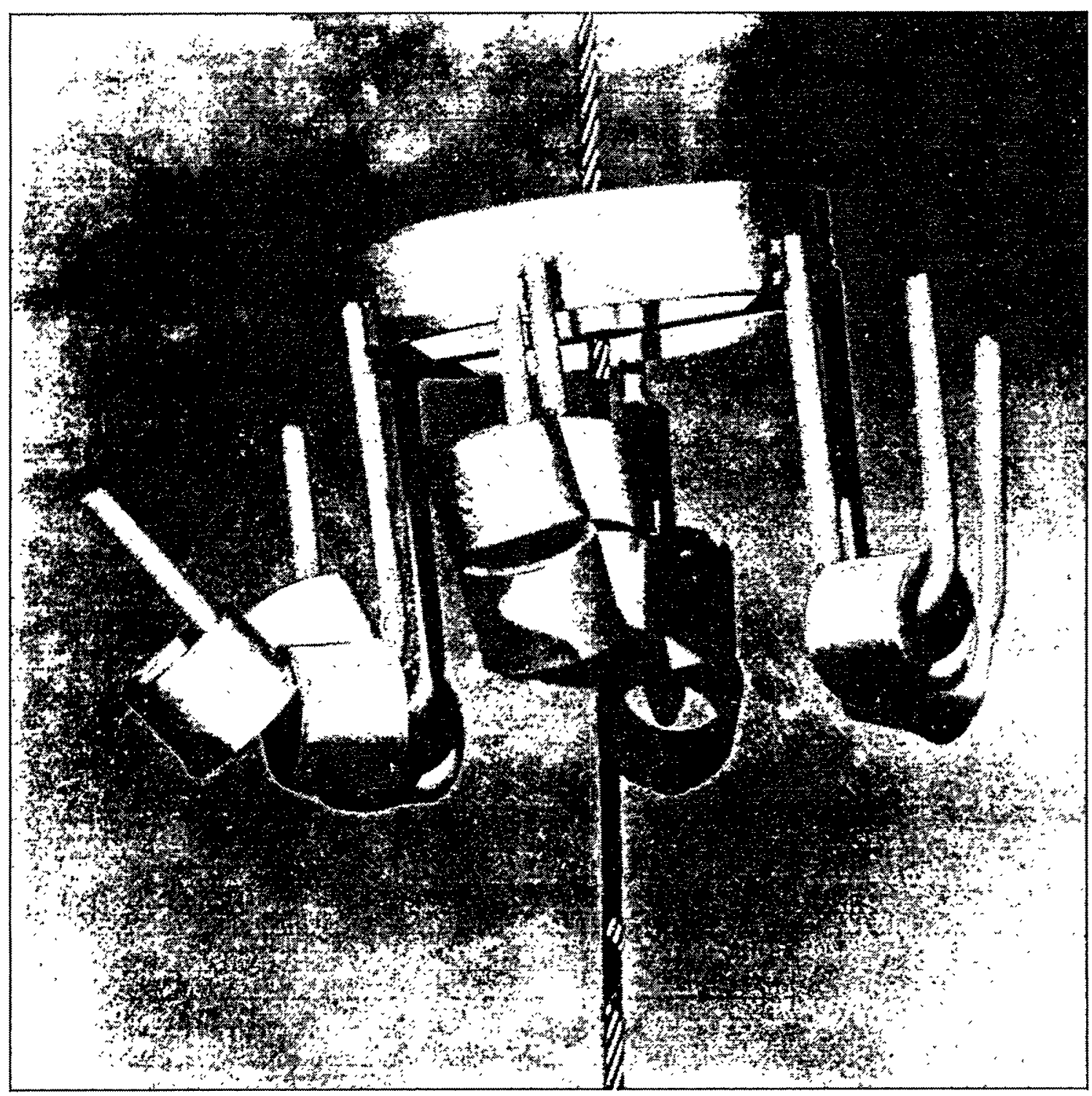

Figure 4. Corrosion Specimen Test Jig. 


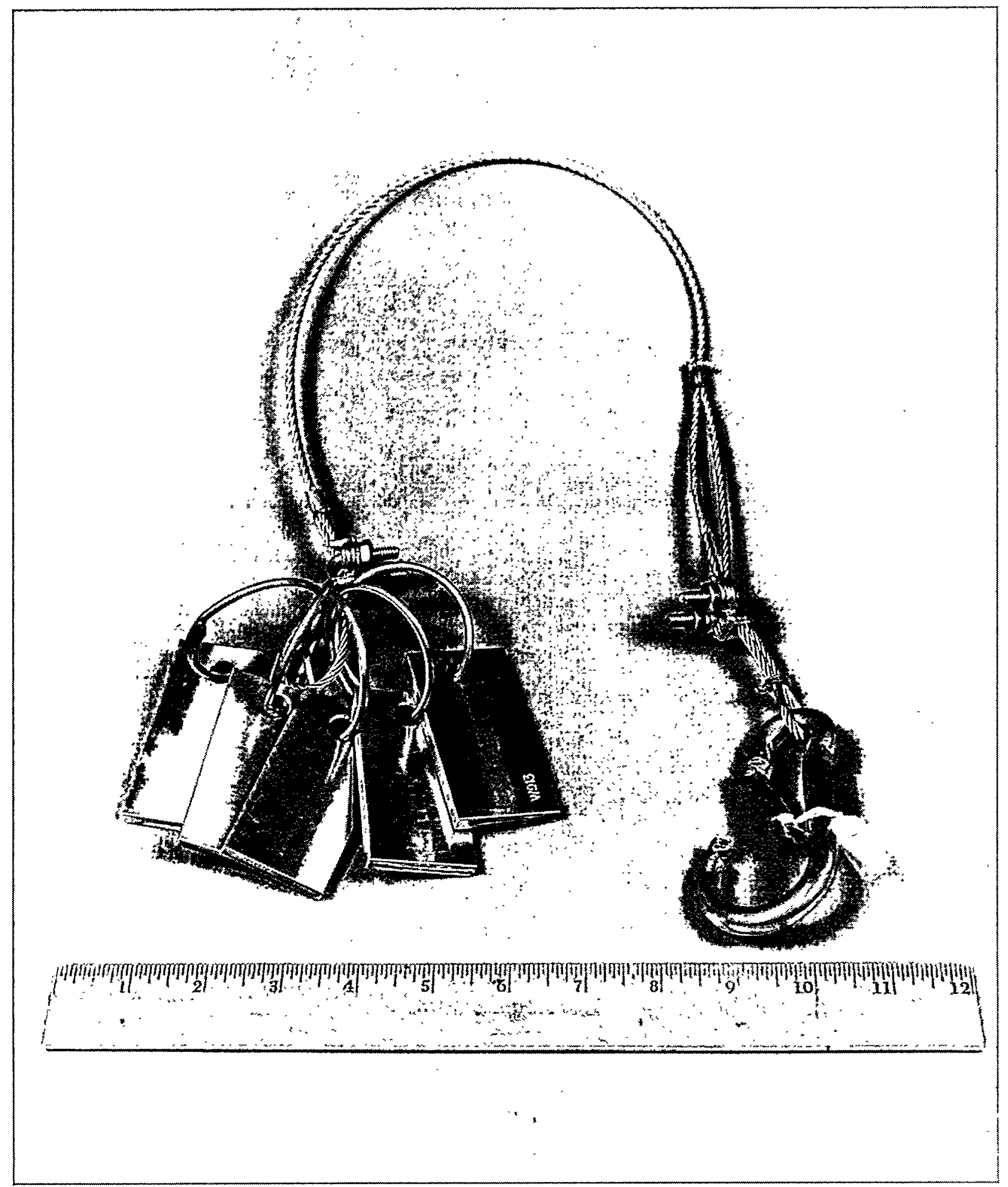

Figure 5. Corrosion Coupon Assembly for Tank Bottom Evaluation. 


\section{TEST RESULTS}

The latest (and final) set of corrosion test coupons was recovered from Tank WM-182 on September 1, 1999 and treated as described in the previous section. The coupon support jigs, (including the new assembly of corrosion coupons that was added in 1988 to monitor the tank bottom conditions), were found to be in place as expected. The cable and jigs appeared to be in excellent condition with no observed localized corrosion. A white deposit was observed on the support cable, coupons, and coupon support jigs.

All of the remaining coupons were recovered. A total of 45 coupons (all that remained in the tank) were retrieved: 5 from the tank bottom, 14 from the 18 -inch level above the tank bottom, 21 from the 36-inch level, and 5 from the 72-inch level. The appearances of typical examples of both types of coupons are shown in Figures 6 and 7. The coupons sets retrieved from each of the four levels are shown in Figures 8, 9, 10, and 11.

The highest average corrosion rate for a set of coupons exposed at any level in the tank was $1.2 \mathrm{x}$ $10^{-2}$ mil per year at the 72 -inch level (Table 2). This calculates to a maximum average metal loss of $5.1 \times 10^{-1} \mathrm{mil}(0.00051$ inch or $0.16 \%$ of the thickness of the tank wall) over 44.4 years of vessel service. The maximum corrosion rate observed for any single coupon from this tank was $1.24 \times 10^{-2}$ mil per year. Calculations using this maximum corrosion rate indicate a metal loss from the internal surfaces of the vessel of $5.5 \times 10^{-1} \mathrm{mil}(0.00055 \mathrm{inch}$ or $0.18 \%$ of the thickness of the tank wall) over the 44.4 years of tank service. WM-182 has a corrosion allowance of 50 mil (0.050 inch).

It should be noted that the reported corrosion rates in Table 2 are uniform corrosion rates. Visual examination of the seamless pipe corrosion coupons under a binocular microscope at $20 \mathrm{X}$ disclosed minor localized corrosion in the form of end grain attack on the end of the coupons (cut edges). There was also evidence of very slight pit initiation parallel to the extrusion marks on the surface of the seamless pipe coupons. Such end grain attack and random pitting along the extrusion marks are a function of the coupon fabrication due to directional aspects of metal grains formed by rolling and metal impurities smeared during extrusion. These types of effects would not normally be seen in the tank construction which used metal plates that are welded together and situated such that the end grains are not exposed to the contents of the tank. In the past, a specific area of concern has been the bottom of the tank where accumulated solids could potentially cause accelerated uniform corrosion rates or localized corrosion. However, examination of the five welded tank bottom coupons, placed on the bottom of the tank in 1988, did not reveal any increase in uniform corrosion rates or any localized corrosion (Figures 6 and 8). Indeed, the lowest corrosion rates observed were in the coupons retrieved from the bottom of the tank. 
Table 3 presents a summary of Tank Farm corrosion data available from previous reports (References 1,2,3, and 4). It lists the average uniform corrosion rates indicated by test coupons removed from Tank WM-182 periodically throughout its operating life and it estimates tank metal losses based on the assumption that the indicated corrosion rate continued constantly over the entire 44.4 years of exposure. These data are based on weight losses from the test coupons and the lengths of coupon exposures to the liquids contained in the tank. The corrosion rates are generally higher for the first period of exposure. This may be attributed to the fact that available 1962 report data reflect only maximum corrosion rates which may have contributed to a positive (conservatively high) bias, or it may be attributed to the well known phenomenon of accelerated corrosion of a freshly exposed new metal surface. The same phenomenon occurs with cyclic corrosion tests of metal alloys in a laboratory setting in which the first cycle corrosion rates are expected to be higher than the rates of subsequent cycles. 


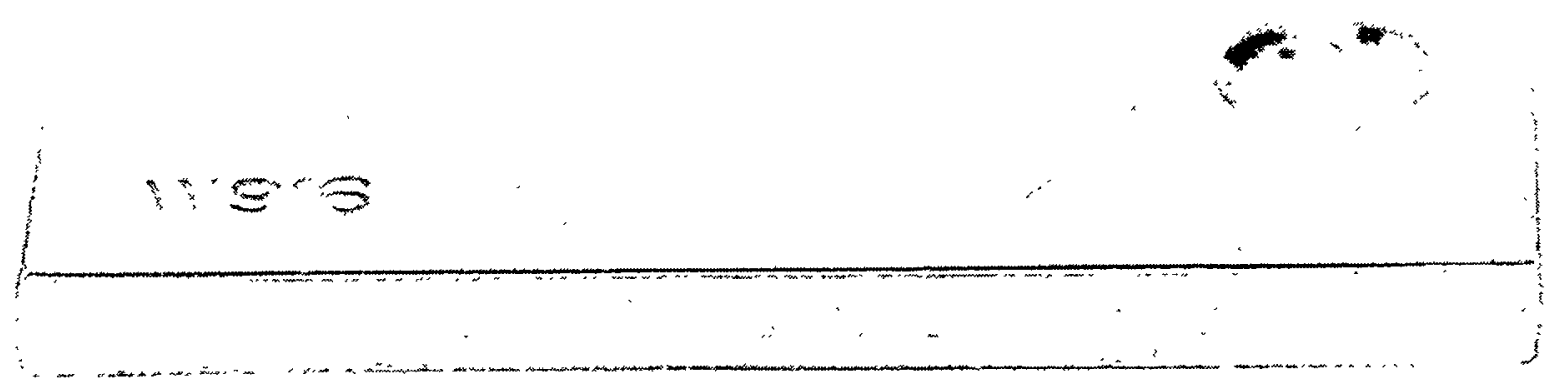

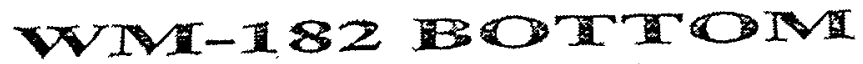
COUPON

Figure 6. Typical Tank Bottom Welded Corrosion Coupon after 11.4 Years Exposure. (Actual size 3 inches $\times 1.5$ inches $\times 0.25$ inch thick)

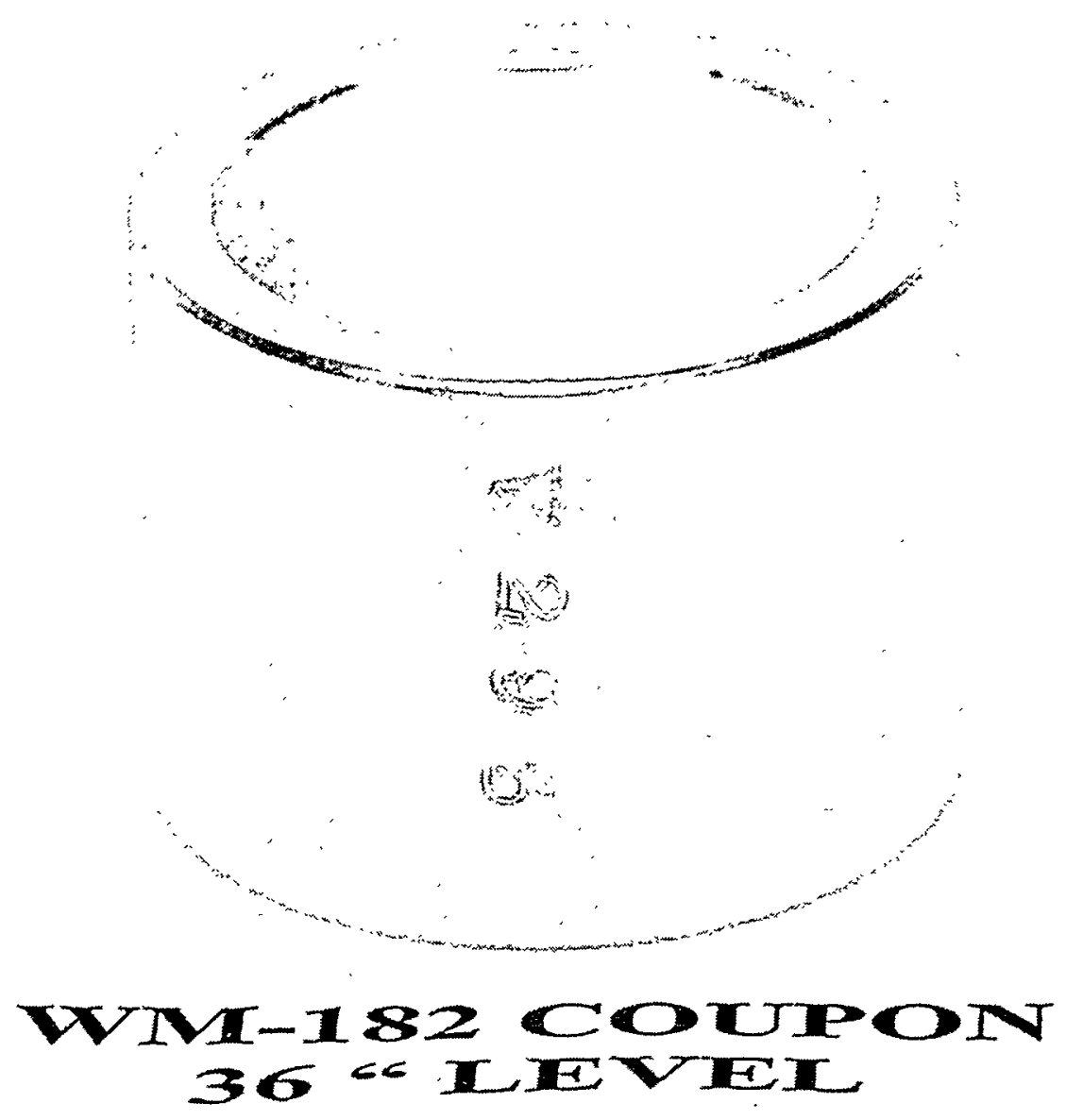

Figure 7. Typical Seamless Pipe Corrosion Coupon after 28.3 Years Exposure. (Actual size approximately 1.3 inches outside diameter and one inch long) 

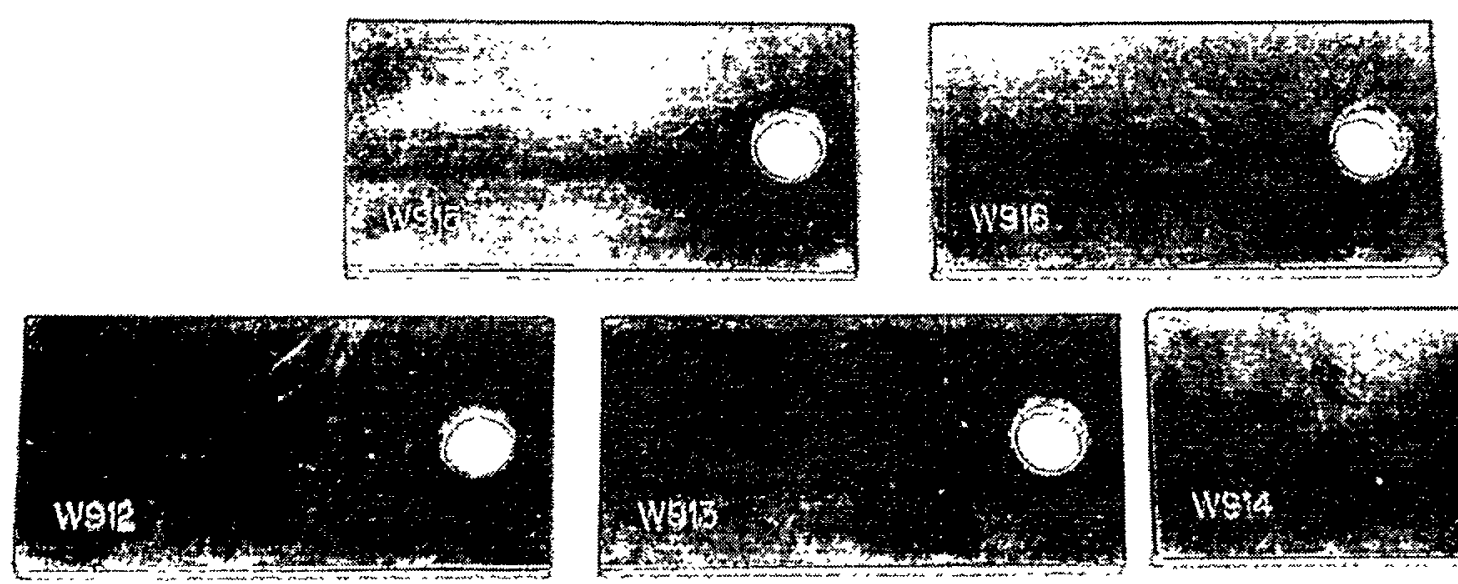

\section{CORROSION COUPON- VESSEL WM-182 BOTTOM - 11.4 YEARS EXPOSURE}

Figure 8. Welded Bottom Type 304L Stainless Steel Coupons - 0 Inch Level (Tank Bottom).

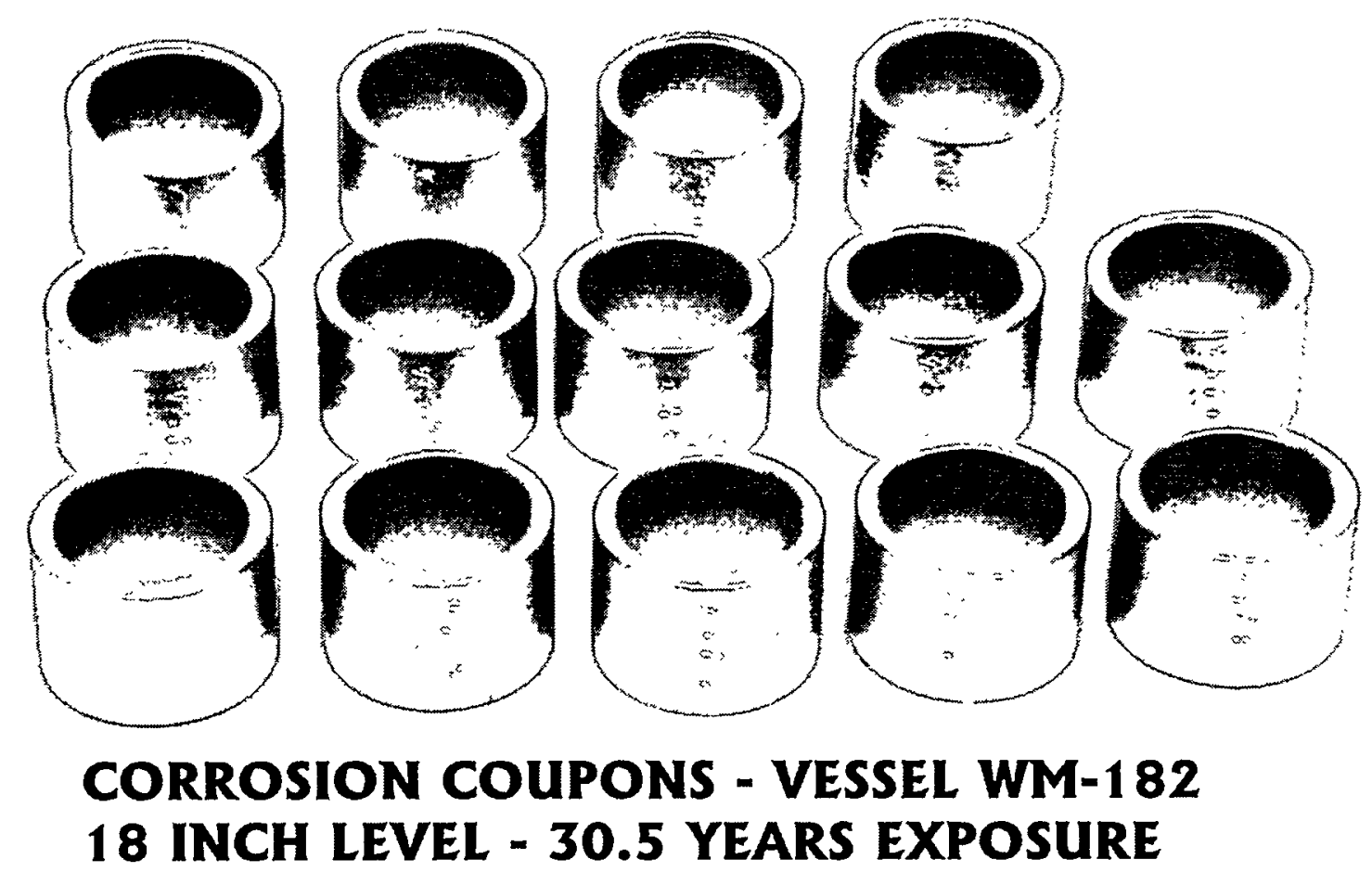

Figure 9. Seamless Type 304L Stainless Steel Pipe Corrosion Coupons - 18 Inch Level. (Coupons fabricated from 1-inch Schedule 40 pipe) 


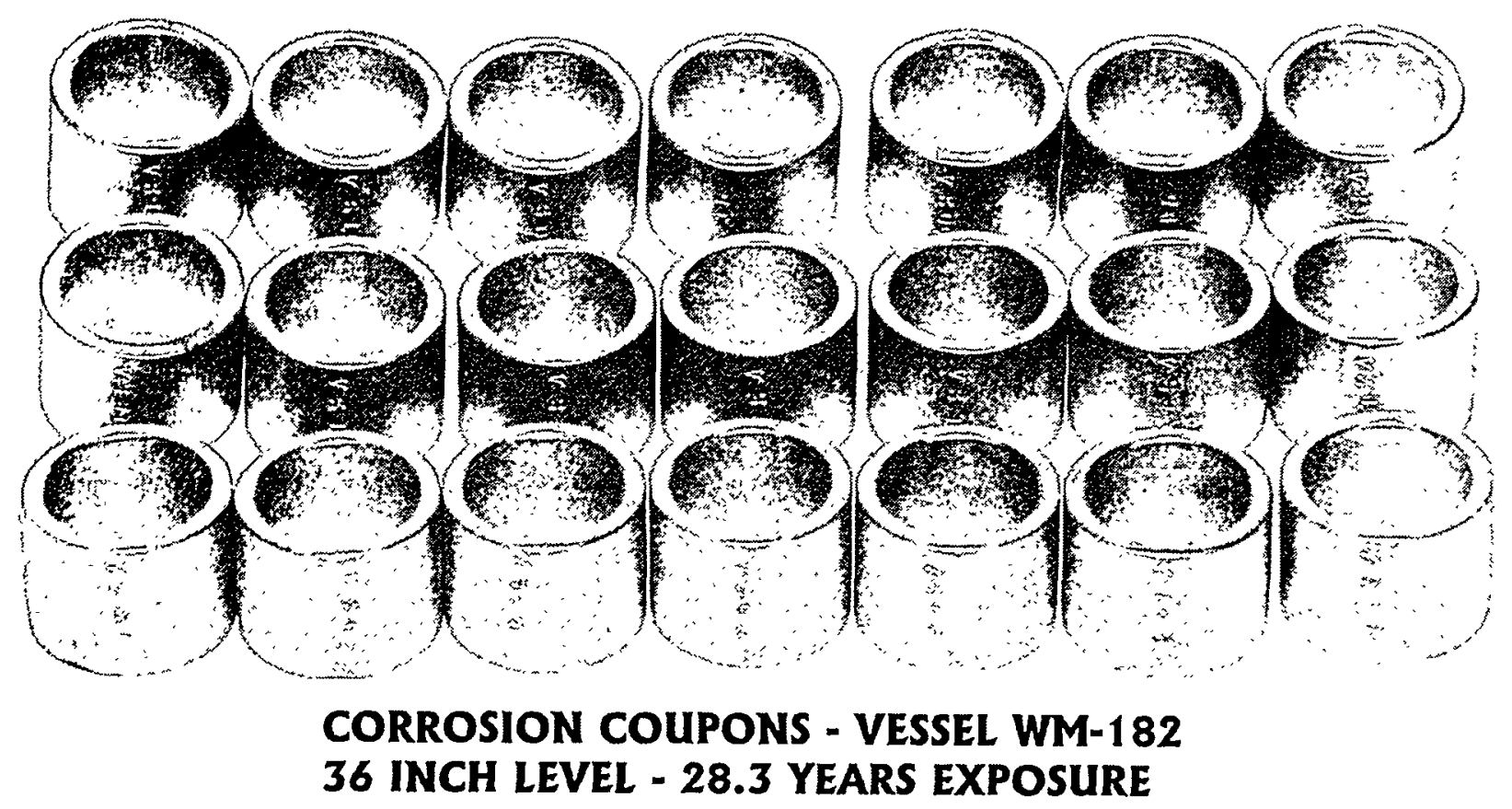

Figure 10. Seamless Type 304L Stainless Steel Pipe Corrosion Coupons - 36 Inch Level.

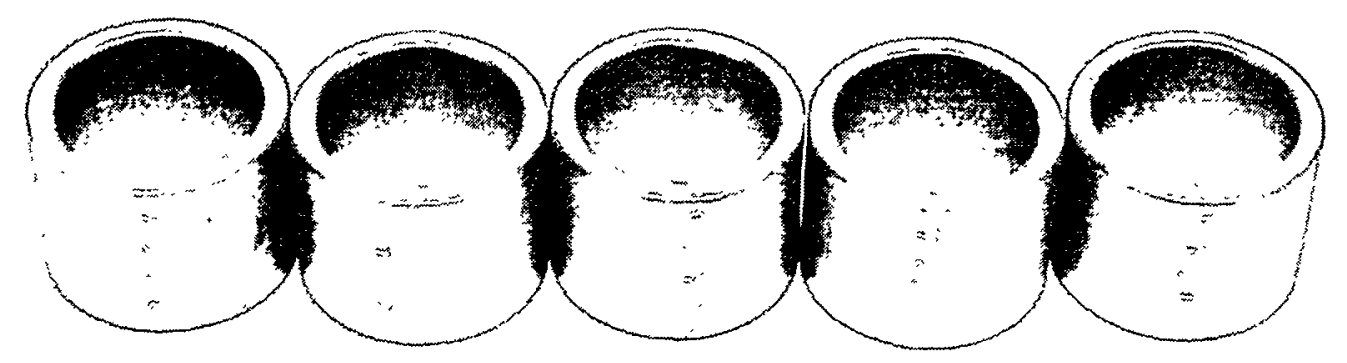

CORROSION COUPONS - VESSEI WM-182 72 INCE LEVEL - 26.5 YEARS EXPOSURE

Figure 11. Seamless Type 304L Stainless Steel Pipe Corrosion Coupons - 72 Inch Level. 
Table 2. Summary of 1999 Corrosion Coupon Data for Waste Tank WM-182.

\begin{tabular}{|c|c|c|c|c|c|c|c|c|}
\hline $\begin{array}{l}\text { Initial Tank } \\
\text { Service } \\
\text { Date }\end{array}$ & $\begin{array}{l}\text { Tank } \\
\text { Construction } \\
\text { Material }\end{array}$ & $\begin{array}{l}\text { Tank } \\
\text { Service } \\
\text { (Years) }\end{array}$ & $\begin{array}{l}\text { Coupon } \\
\text { Exposure } \\
\text { (Years) }\end{array}$ & $\begin{array}{l}\text { Exposure } \\
\text { Level (Inches } \\
\text { above Tank } \\
\text { Floor) }\end{array}$ & $\begin{array}{l}\text { Average } \\
\text { Uniform } \\
\text { Corrosion } \\
\text { Rate (mpy) }\end{array}$ & $\begin{array}{l}\text { Average Indicated Metal } \\
\text { Loss from Tank Internal } \\
\text { Surface Extrapolated to } \\
\text { Total Tank Service to Date } \\
\text { (mil) }\end{array}$ & $\begin{array}{l}\text { Maximum } \\
\text { Uniform Corrosion } \\
\text { Rate Observed } \\
\text { (mpy) }\end{array}$ & $\begin{array}{l}\text { Metal Loss from } \\
\text { Tank based on } \\
\text { Maximum Corrosion } \\
\text { Rate (mil) }\end{array}$ \\
\hline \multirow[t]{5}{*}{ May 1955} & Type 304LSS & 44.4 & - & -non & - - - - & 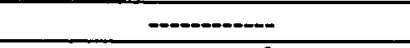 & $1.2 \times 10^{-2}\left(72^{\prime \prime}\right)$ & $5.5 \times 10^{-1}$ \\
\hline & & & 11.4 & 0 & $3.5 \times 10^{-4}$ & $1.6 \times 10^{-2}$ & $5.3 \times 10^{-4}$ & -------- \\
\hline & & & 30.5 & 18 & $8.6 \times 10^{-3}$ & $3.8 \times 10^{-1}$ & $9.0 \times 10^{-3}$ & 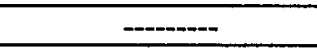 \\
\hline & & & 28.3 & 36 & $1.1 \times 10^{-2}$ & $4.9 \times 10^{-1}$ & $1.1 \times 10^{-2}$ & - \\
\hline & & & 26.5 & 72 & $1.2 \times 10^{-2}$ & $5.1 \times 10^{-1}$ & $1.2 \times 10^{-2}$ & -...- \\
\hline
\end{tabular}

Table 3. Summary of Corrosion Coupon Data for the Life of Tank WM-182.

\begin{tabular}{|c|c|c|}
\hline Report & $\begin{array}{l}\text { Coupon Corrosion Rate (Ave.) })^{(\mathrm{a})} \\
\mathrm{mpy}^{(\mathrm{b}, \mathrm{c}, \mathrm{d})}\end{array}$ & $\begin{array}{c}\text { Tank Metal Loss } \\
\text { Mil } \\
\end{array}$ \\
\hline \begin{tabular}{l}
\multicolumn{1}{c}{1962 Report } \\
(Coupons Recovered \\
1962 or Earlier)
\end{tabular} & $1.2 \times 10^{-1}$ & $8.1 \times 10^{-1}$ \\
\hline $\begin{array}{c}1976 \text { Report } \\
\text { (Coupons Recovered } \\
1973 \text { ) }\end{array}$ & $7.0 \times 10^{-3}$ & $1.3 \times 10^{-1}$ \\
\hline$\frac{1983 \text { Report }}{\left(\begin{array}{c}\text { (Coupons Recovered } \\
1981)\end{array}\right.}$ & $9.5 \times 10^{-3}$ & $2.5 \times 10^{-1}$ \\
\hline $\begin{array}{c}\text { 1988 Report } \\
\text { (Coupons Recovered } \\
\text { 1987-88) }\end{array}$ & $1.3 \times 10^{-2}$ & $4.3 \times 10^{-1}$ \\
\hline $\begin{array}{c}1999 \text { Report } \\
\text { (Coupons Recovered } \\
\text { 1999) } \\
\end{array}$ & $1.2 \times 10^{-2}\left(72^{\prime \prime}\right)$ & $5.1 \times 10^{-1}$ \\
\hline
\end{tabular}

(a) No average data available for the 1962 report. Maximum data used instead.

(b) "mpy" stands for "mils per year". "mil" is a unit of measurement equal to 0.001 inch.

(c) New coupons placed in service June 1978

(d) 18-inch level unless otherwise noted.

(e) Total tank metal loss is based on the assumption that this rate of corrosion occurred continuously for the entire 44.4 years of exposure. 


\section{CONCLUSION}

The 1999 data indicate that the average uniform corrosion rate for Tank WM-182 has been $1.2 \mathrm{x}$ $10^{-2}$ mil per year. This corrosion rate indicates very low uniform corrosion for the internal surfaces of the austenitic Type 304L stainless steel tank. Corrosion test coupons retrieved from four different levels in the tank do not indicate any significant localized corrosion such as cracking, preferential weld attack, pitting, or heat affected weld zone attack.

Based on the WM-182 coupon evaluations, which have occurred throughout the life of the tank, the metal loss from the tank wall is not expected to exceed $5.5 \times 10^{-1} \mathrm{mil}(0.00055 \mathrm{inch})$. For purposes of waste storage, this is a negligible amount of metal loss. 


\section{REFERENCES}

1. T. L. Hoffman, Corrosion Evaluation of Stainless Steels Exposed in ICPP High-Level Radioactive Waste Tanks, IDO-14600, December 1962

2. T. L. Hoffman, Corrosion Evaluation of Stainless Steels in ICPP High-Level Radioactive Waste Service, ICP-1072, June 1976

3. T. L. Hoffman et al., Evaluation of Stainless Steel Tank Corrosion in CPP High-Level Radioactive Waste Service, ENICO-1131, April 1983

4. C. A. Zimmerman, Corrosion Evaluation of ICPP High-Level Liquid Waste Storage Tanks, WINCO-1064, April 1989 